\title{
NUMERICAL MODELLING OF THE SUBSOIL ZONE BETWEEN STONE COLUMNS
}

\author{
Jakub STACHO ${ }^{1 *}$, Monika SULOVSKA ${ }^{1}$
}

\section{Abstract}

Designing the improvement of soil using stone columns is usually based on simplified analytical or numerical models. Stone columns installed using a vibro-replacement technique can cause radial displacement of the original soil. It can cause radial compaction of the soil and increase the values of the strength and deformation properties, which are usually ignored in a practical design. The paper presents the results of a numerical analysis of a road embankment based on subsoil improved using stone columns. The changes in the properties of the original subsoil compacted by stone columns were analysed and taken into consideration in the models. The results showed that a model with homogenization of the subsoil and a model with stone columns transferred to continuous walls show similar results of the final settlement as well as the consolidation times. The differences between the values computed and measured were about 28 - $36 \%$. Taking into account the compacting effect of the original subsoil, the model with stone columns transferred to continuous walls allowed for the determination of more precise results when the difference between the values computed and measured was about $10 \%$.

\section{Address}

1 Dept. of Geotechnics, Faculty of Civil Engineering, Slovak University of Technology in Bratislava, Bratislava, Slovakia

* Corresponding author: jakub.stacho@stuba.sk

\section{Key words}

- Stone columns,

- Soil improvement,

- Settlement

- Numerical modelling.

\section{INTRODUCTION}

Designing the improvement of soil using stone columns falls amongst the usual roles of geotechnical engineering. Currently, there are a number of calculation models and methods for the design of these stone columns. Methods are constantly being developed and modified in order to achieve the most accurate design results. Greenwood (1970) was one of the first authors who devised the empirical and analytical equations for determining the resistance of a single stone column. The calculation method assumed a bulging stone column and passively applied horizontal pressure on the earth. The bulging mechanism was first described and analysed by Vesic (1972). He applied the cavity expansion theory to determine changes in the stresses and properties around a stone column. The theory was later modified by Mecsi (2013). He described the principles and use of the theory for the latest geotechnical problems.
A theoretical model for determining the bearing capacity of a single stone column was introduced by Madhav and Vitkar (1978). Priebe (1995) was the first to introduce a general shear-failure pattern and the equivalent width of a foundation for predicting the resistance of a stone column group. The method assumed the angle of the shear resistance of the original subsoil and the averaged value of the cohesion of the assumed equivalent foundation. Priebe (2005) proposed a similar method for the stone columns in sandy soils. Hu (1995) reported that the shear-failure mechanism of a combined stone column-soil system was the collapse pattern for an improved soil mass. His observations with respect to the failure mechanism were conducted based on numerical modelling by Shahu and Reddy (2011). Stuedlein and Holtz (2013) reported that the analytical models available are not entirely satisfactory for a wide range of conditions. Stuedlein and Holtz (2014) observed a similar trend for determining settlement based on the theoretical methods available. 
The most complex method for designing improved soil using stone columns is numerical modelling (FEM), which was devised by, e.g., Wehr (1999), Weber (2009), and Fiala et al. (2014). In Slovakia, numerical modelling, especially the finite element method (FEM), is used more and more in practise. The numerical models are usually created as a plane strain task. The improved soil is modelled using homogenization of the subsoil (Barksade and Bachus, 1983) or transformation of the stone columns to continuous walls (VanImpe and DeBeer, 1983). Installing stone columns using the vibro-replacement technique is a typical type of displacement technology. This technology causes the compaction of the original subsoil between the stone columns, which leads to its improvement. The improvement is usually not taken into account in the above-stated methods of numerical modelling. The aim of the paper presented is the numerical modelling of stone columns, but also takes into account the improvement of the original subsoil between them.

The newly constructed R2 highway in Slovakia included many embankments that were founded on subsoil improved using stone columns. The settlement of the embankment was measured using horizontal inclinometers. The analysis presented includes a comparison of the results of the measurements with the results of the numerical analysis of the selected KM3.940 cross-section.

\section{CREATING THE NUMERICAL MODEL}

The numerical model of the road embankment based on the improved subsoil was created as a plane strain model using Plaxis geotechnical software. The total dimensions of the model created were

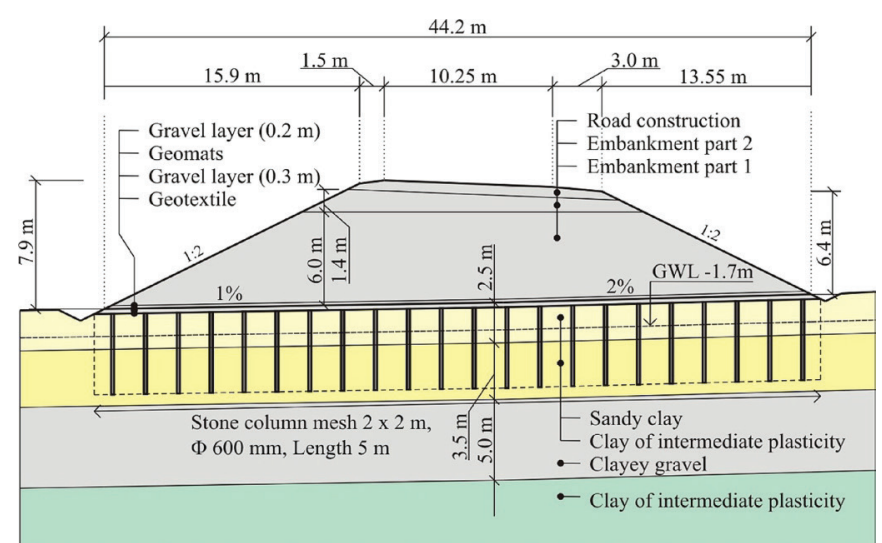

Fig. 1 Scheme of the geotechnical model of the cross-section analysed, according to Stacho et al. (2018)
$120 \mathrm{~m}$ (width) $\times 40 \mathrm{~m}$ (height). Part of the model focused on the road embankment and the stone columns, as shown in Fig. 1. The surface of the original terrain had an inclination of about 1-2\%. The subsoil consists of quaternary and neogene soils. The first layer, with a thickness of $2.5 \mathrm{~m}$, consists of sandy clay. The second layer with a thickness of $3.5 \mathrm{~m}$ consists of clay of an intermediate plasticity. The third layer is represented by clayey gravel and has a thickness of about 5 $\mathrm{m}$. A neogene subsoil consisting of clay of an intermediate plasticity lies below the gravel layer. The stable ground water level (GWL) was at a depth of about $1.7 \mathrm{~m}$ below the surface.

The height of the embankment was 6.4 to $7.9 \mathrm{~m}$, depending on the inclination of the terrain and the top of the embankment. The embankment was constructed in two phases. The height of the embankment during the graded first construction phase was about $6 \mathrm{~m}$. The embankment was based on a consolidation layer of compacted gravel well graded with a thickness of $0.5 \mathrm{~m}$, which was reinforced using geomats. A geotextile layer was spread on the top of the surface and the separate original subsoil and consolidation gravel layer. The mesh of the finite elements of the model for the road embankment is shown in Fig. 2. The soils were modelled using the Hardening Soil (HS) material model. The fine-grained soil were modelled as undrained A type (Plaxis, 2011), and the coarse-grained soil were modelled as drained (Plaxis, 2011). The geotextile and the geomats were modelled as a geogrid (Plaxis, 2011). The main input soil properties used in the numerical modelling are shown in Tab. 1.

The improvement of the subsoil below the embankment was modelled using three different methods. The first method was the homogenisation of the subsoil. The method takes into account only homogeneous soil without direct modelling of the stone columns. The properties of the homogenized soil are equivalent properties in the zone of improvement determined according to the method presented by, e.g., Turček et al. (2005). The stone columns significantly reduce the consolidation time. This effect was obtained by modelling drains

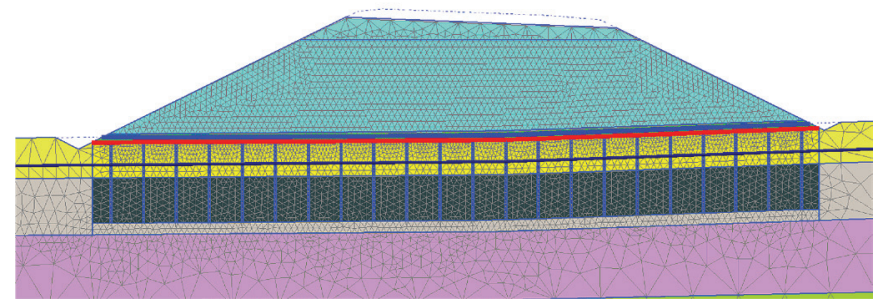

Fig. 2 Mesh of the finite elements of the numerical model based on the road embankment

Tab. 1 Soil properties input for the numerical modelling

\begin{tabular}{|c|c|c|c|c|c|c|c|c|}
\hline \multirow{2}{*}{\multicolumn{2}{|c|}{ Parameter / Unit }} & \multicolumn{7}{|c|}{ Material } \\
\hline & & \multirow{2}{*}{$\begin{array}{c}\text { Layer } 1 \\
19.8\end{array}$} & \multirow{2}{*}{$\begin{array}{c}\text { Layer } 2 \\
19.8\end{array}$} & \multirow{2}{*}{$\begin{array}{c}\text { Layer } 3 \\
19.5\end{array}$} & \multirow{2}{*}{$\begin{array}{c}\text { Layer } 4 \\
19.8\end{array}$} & \multirow{2}{*}{$\begin{array}{c}\text { Consolidation gravel layer } \\
21\end{array}$} & \multirow{2}{*}{$\begin{array}{c}\text { Stone columns } \\
17.4\end{array}$} & \multirow{2}{*}{$\begin{array}{c}\text { Embankment } \\
19\end{array}$} \\
\hline$\gamma$ & $\mathrm{kN} \cdot \mathrm{m}^{-3}$ & & & & & & & \\
\hline$\gamma_{\text {sat }}$ & $\mathrm{kN} \cdot \mathrm{m}^{-3}$ & 20.2 & 20.1 & 20.72 & 20.1 & 21.55 & 19.57 & 20.45 \\
\hline$E_{50}=E_{\mathrm{oed}}$ & MN.m $^{-2}$ & 12.26 & 19.14 & 67.57 & 40.88 & 108 & 82.5 & 48 \\
\hline$E_{\text {ur }}$ & MN.m ${ }^{-2}$ & 36.78 & 57.42 & 202.71 & 122.64 & 324 & 247.5 & 144 \\
\hline$m$ & - & 0.8 & 0.7 & 0.7 & 0.7 & 0.5 & 0.5 & 0.7 \\
\hline$\varphi^{\prime}$ & $\circ$ & 21.7 & 16.7 & 30 & 18.8 & 36.1 & 40 & 21 \\
\hline$\psi^{\prime}$ & $\circ$ & 0 & 0 & 0 & 0 & 6.1 & 10 & 0 \\
\hline$c^{\prime}$ & $\mathrm{kN} \cdot \mathrm{m}^{-2}$ & 14 & 18 & 4 & 21 & 2 & 1 & 30 \\
\hline$k_{x}=k_{y}$ & m.day ${ }^{-1}$ & 0.000235 & 0.00146 & 0.00149 & 0.00149 & 86.4 & 86.4 & 0.0864 \\
\hline
\end{tabular}


in place of the stone columns. The transformation of the coefficient of filtration from a 3D task to a 2D task was determined according to Tran and Mitachi (2008). The adjust of the coefficient of filtration was necessary because the plane strain model assumed stone columns as a linear elements, which has greater area of the shaft and this

a, homogenization of the subsoil with geodrains

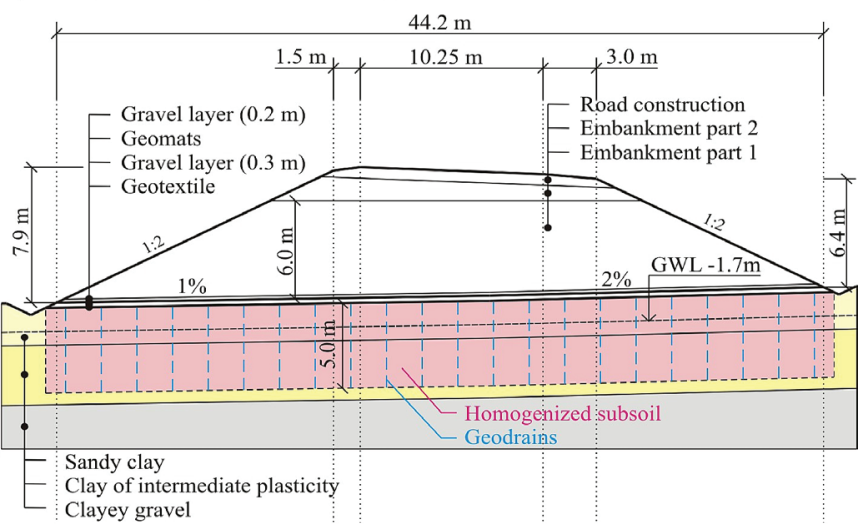

b, transformation of the stone columns to continuous walls

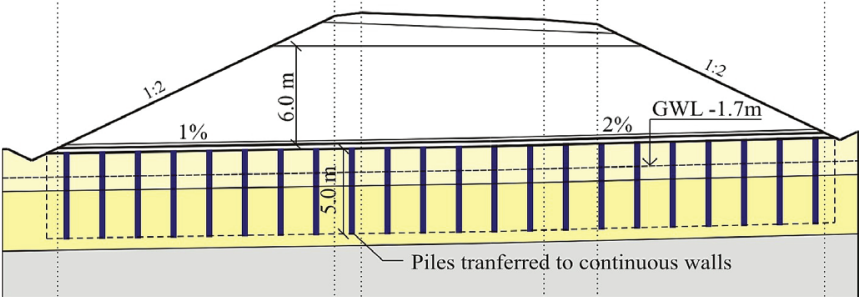

c, transformation of the stone columns to continuous wallstaking into account the compaction of the original subsoil between stone columns

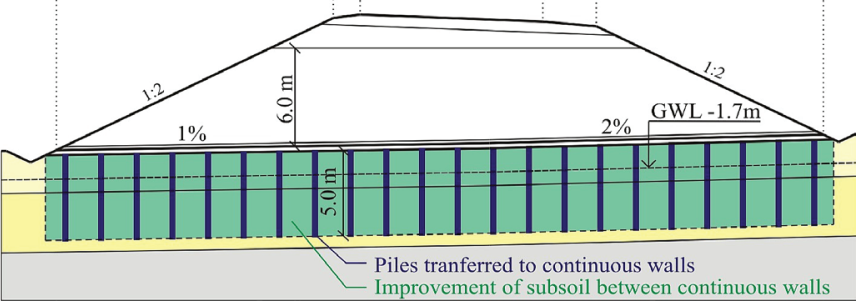

Fig. 3 Schemes of the numerical models with different methods of modelling the stone columns

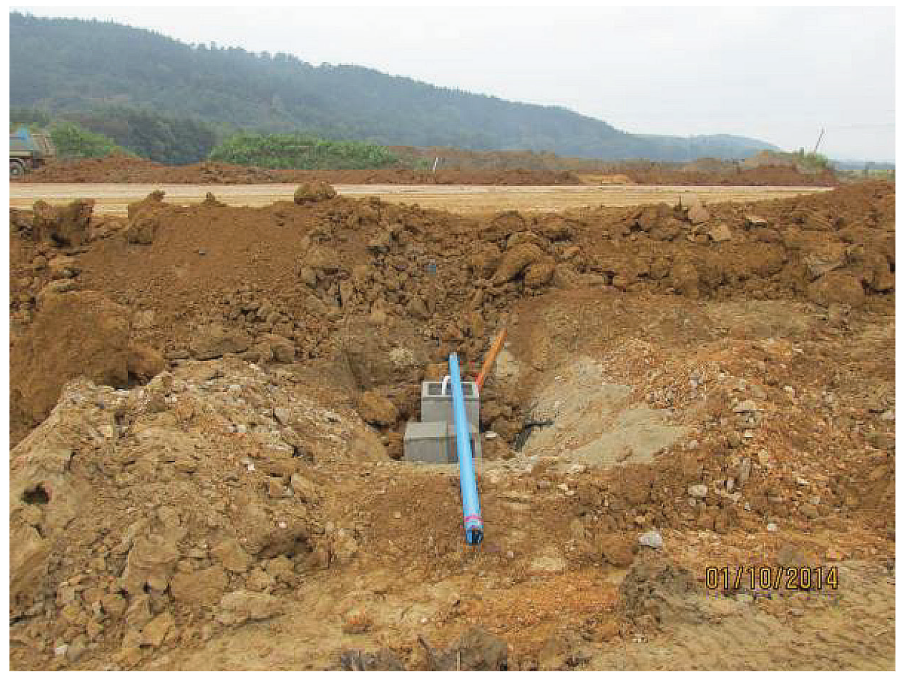

would have a negative impact on the consolidation time. The model is marked as Model A (Fig. 3a).

The second model (Model B) takes into account the stone columns as continuous walls that have the same volume as stone columns in a row. In the case of a stone column with a diameter of 0.6 $\mathrm{m}$ and installed in a $2 \times 2 \mathrm{~m}$ square mesh, the width of the continuous wall was equal to $0.14 \mathrm{~m}$. The scheme of Model B is shown in Fig. $3 \mathrm{~b}$. The third model (Model C) also modelled the stone columns as a continuous wall, but it also takes into account the improvement (compaction) of the original subsoil between the columns. The improvement was taken into account by changing the unit weights, the oedometric modules, and the coefficients of the lateral earth pressure of the improved soils. The process of determining these properties is described below. The scheme of Model C is shown in Fig. 3c.

\section{CONSTRUCTION OF THE ROAD EMBANKMENT AND MEASUREMENT OF THE SETTLEMENT OF THE BASE}

Stone columns with a diameter of $0.6 \mathrm{~m}$ and a length of $5 \mathrm{~m}$ were installed in the $2 \times 2 \mathrm{~m}$ square plan layout in the first construction phase. The stone columns were installed using the vibro-replacement technique with a bottom feeding. A horizontal inclinometer for measuring the embankment's settlement was installed after all the stone columns were installed. The installation of the horizontal inclinometer is shown in Fig. 4. The general information about the geotechnical monitoring at the site was presented by Frankovská, et al. (2017). An unwoven separating geotextile was spread on the terrain, which was already improved by the stone columns. The first part of the consolidation layer made of gravel with a fine content with a thickness of 0.3 $\mathrm{m}$ was created. Before the construction of the second part of the consolidation layer with a thickness of $0.2 \mathrm{~m}$, a geomat with a $55 \mathrm{kN} \cdot \mathrm{m}^{-1}$ tensile strength was laid. The installation of the consolidation layers with the geotextile and geomat took about 20 days. The first part of the road embankment with a height of about $6 \mathrm{~m}$ was constructed in the following 30 days. Construction of the second part to the top of the road embankment, which took about 25 days, started after 287 days. The settlement of the road embankment was recorded during the whole construction time. The measured settlements with the steps of the construction are shown in Fig. 5.

The numerical models fully respected the progress of the construction. The construction phases modelled as well as the times of

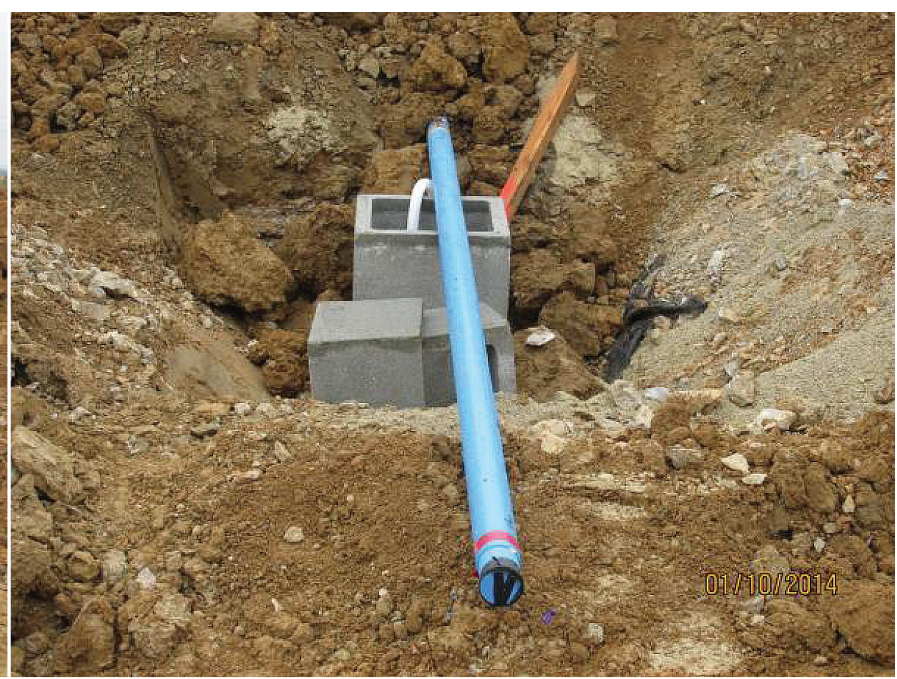

Fig. 4 Installation of the horizontal inclinometer at the KM 3.98 cross-section 


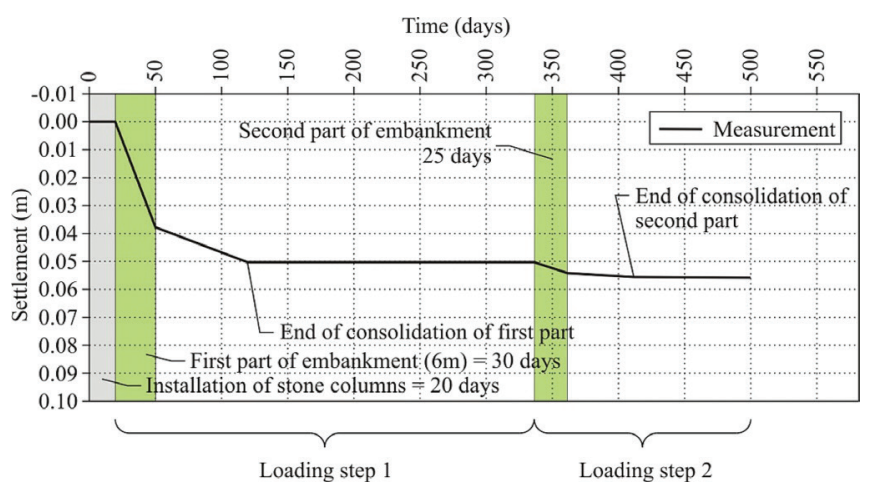

Fig. 5 Progress of the construction and results of the settlement of the embankment base

each phase and the time elapsed since the beginning of the construction are summarized in Tab. 2. The differences between Models $A, B$ and $C$ are shown in Phase No. 3, the Stone Columns. This phase modelled the improvement of the subsoil using the stone columns with the different methods according to Fig. 3. The Model A included activation of homogenized subsoil, drains and the change of the coefficient of permeability. The Model B included activation of stone columns (transfered to continuous walls) and the change of the coefficient of permeability. The Model C included activation of stone columns, improved properties between stone columns as well as the change of the coefficient of permeability.

Model $A$ takes into account the homogenisation of the improved subsoil. In general, the averaged parameter $X$ was determined using the following equation:

$$
X=\frac{X_{S} A_{S}+X_{o r} A_{o r}}{A_{S}+A_{o r}}
$$

where $X_{\mathrm{s}}$ is the property of the stone column, $A_{\mathrm{s}}$ is the area of the stone column $\left(0.283 \mathrm{~m}^{2}\right.$ in this case); $X_{\text {or }}$ is the property of the original subsoil that was calculated, and $A_{\text {or }}$ is the area of the original subsoil $\left(3.717 \mathrm{~m}^{2}\right.$ in this case). The averaged properties of the homogenized soils (Layer 1 Homogenized and Layer 2 Homogenized) computed, which were used in Model A, are shown in Tab. 3. Model $B$ takes into account the unchanged properties of the original subsoil,

Tab. 2 Construction phases of the numerical modelling

\begin{tabular}{|l|l|l|l|l|}
\hline Phase No. & Phase Name & Calculation type & Phase Time (day) & Total Time (day) \\
\hline 1 & Initial phase & $\mathrm{K}_{0}$ procedure & 0 & 0 \\
\hline 2 & Removing the topsoil & Consolidation & 2 & 2 \\
\hline 3 & Stone columns & Plastic & 0 & 2 \\
\hline 4 & Consolidation & Consolidation & 10 & 12 \\
\hline 5 & Geotextile & Consolidation & 2 & 14 \\
\hline 6 & Consolidation gravel layer & Consolidation & 2 & 16 \\
\hline 7 & Geomat & Consolidation & 2 & 18 \\
\hline 8 & Consolidation gravel layer & Consolidation & 2 & 20 \\
\hline 9 & Embankment 6 m & Consolidation & 30 & 50 \\
\hline 10 & Consolidation & Consolidation & 287 & 337 \\
\hline 11 & Embankment to the top & Consolidation & 25 & 362 \\
\hline 12 & Consolidation & Consolidation & 85 & 447 \\
\hline 13 & Consolidation & Consolidation & $?$ & $?$ \\
\hline
\end{tabular}

Tab. 3 Input properties of the improved soils between the stone columns

\begin{tabular}{|c|c|c|c|c|c|}
\hline \multirow{3}{*}{\multicolumn{2}{|c|}{ Parameter / Unit }} & \multicolumn{4}{|c|}{ Material } \\
\hline & & \multicolumn{2}{|c|}{ Model A } & \multicolumn{2}{|c|}{ Model C } \\
\hline & & Layer 1 Homogenized & Layer 2 Homogenized & Layer 1 Improved & Layer 2 Improved \\
\hline$\gamma$ & $\mathrm{kN} \cdot \mathrm{m}^{-3}$ & 19.59 & 19.59 & 20.77 & 20.77 \\
\hline$\gamma_{\text {sat }}$ & $\mathrm{kN} \cdot \mathrm{m}^{-3}$ & 20.13 & 20.04 & 21.42 & 21.32 \\
\hline$E_{50}=E_{\mathrm{oed}}$ & $\mathrm{MN} \cdot \mathrm{m}^{-2}$ & 16.13 & 22.51 & 19.48 & 39.08 \\
\hline$E_{\mathrm{ur}}$ & MN.m-2 & 48.39 & 67.53 & 58.44 & 117.25 \\
\hline$m$ & - & 0.8 & 0.7 & 0.8 & 0.7 \\
\hline$\varphi^{\prime}$ & $\circ$ & 23.89 & 19.25 & 21.7 & 16.7 \\
\hline$\psi^{\prime}$ & $\circ$ & 0 & 0 & 0 & 0 \\
\hline$c^{\prime}$ & $\mathrm{kN} \cdot \mathrm{m}^{-2}$ & 13.06 & 16.77 & 14 & 18 \\
\hline$k_{\mathrm{x}}=k_{\mathrm{y}}$ & m.day ${ }^{-1}$ & 0.0000363 & 0.000225 & 0.0000363 & 0.000225 \\
\hline$K$ & - & - & - & 2.11 & 1.58 \\
\hline
\end{tabular}


and the continuous walls have the properties of the stone columns (Tab. 1). Model $C$ take into account the improved soil properties of the original subsoil (Layer 1 Improved and Layer 2 Improved). These properties are shown in Tab. 3. The determination of these properties is described below.

\section{DETERMINATION OF THE IMPROVEMENT OF THE SOIL BETWEEN THE STONE COLUMNS}

The stone columns constructed according to the vibro-replacement technique are typical members of the displacement method. The original soil was not removed from the subsoil but was radially displaced. The numerical modelling of this method in the full 3D model or plane-strain model of the full cross-section of the road embankment is very difficult and time-consuming. For these reasons, especially in practise, 2D models (plane strain models) are preferred, and the impact of the technology is ignored or only taken into account by a simple improvement of the deformation properties of the original subsoil.

In the numerical model presented in this article, the effect of the compaction (installation of the stone column) was firstly determined using two simple models: an axisymmetric model with a single stone column and a spatial model with a 3D effect, where the original subsoil (which was between four stone columns) and quadrants of the stone columns were taken into account. The simplest model is an axisymmetric model of a single stone column, see Fig. 6 . The process of installing the stone column was modelled using the method already presented by (Stacho, 2017a). The model allows for a simple determination of the change in the coefficient of the lateral earth pressure and the oedometric modules. A disadvantage of the model is that it does not takes into account the impact of the compaction of the surrounding stone columns on the original subsoil.
The effect of all four stone columns on a compacted unit cell of the original subsoil can only be determined more precisely using a spatial model that takes into account a $2 \times 2 \mathrm{~m}$ unit of the original subsoil and quadrants of the stone columns. The scheme of the ground plan taken into account by the model is shown in Fig. 7. A cross section of the model is shown in Fig. 8. The process of installing a stone column is similar to that of the axisymmetric model. The stone columns were created successively as Nos. 1 - 4 .

This method can only be used in cases when the compaction of the soil made by radial displacement of a single stone column is less than the dimension of the original subsoil unit cell between the groups of stone columns. This effect can be simply verified using the axisymmetric model of a single stone column that has larger dimensions. In other cases when the compaction is greater, the results of the model with four stone columns are distorted because of the boundary conditions of the numerical model.

The $N$-fold change in $E_{\text {oed }}$ caused by the installation of the stone column, which was determined using the axisymmetric and spatial models, is shown in Fig. 9 for the middle of Layer 1 and in Fig. 10 for the middle of Layer 2. The results are presented for the cross-section between stone columns Nos.1 and 3, where the values for $B$ point (Fig. 11) are shown.

The same principle was also used for the determination of the coefficient of the lateral earth pressure. The averaged properties were used in the plane strain numerical model of the road embankment (shown in Fig. 1). The unit weight of the compacted original soil $\left(\gamma_{\text {imp }}\right)$ between the stone columns was determined using a simplified formula as follows:

$$
\gamma_{\text {imp }, i}=\frac{A_{\text {unit }} \gamma_{i}}{A_{\text {unit }}-A_{s c}}
$$

where $A_{\text {unit }}$ is the area of the unit ( $4 \mathrm{~m}^{2}$ in this case); $\gamma_{\mathrm{i}}$ is the unit weight of the original subsoil; and $A_{\mathrm{sc}}$ is the area of a single stone column.

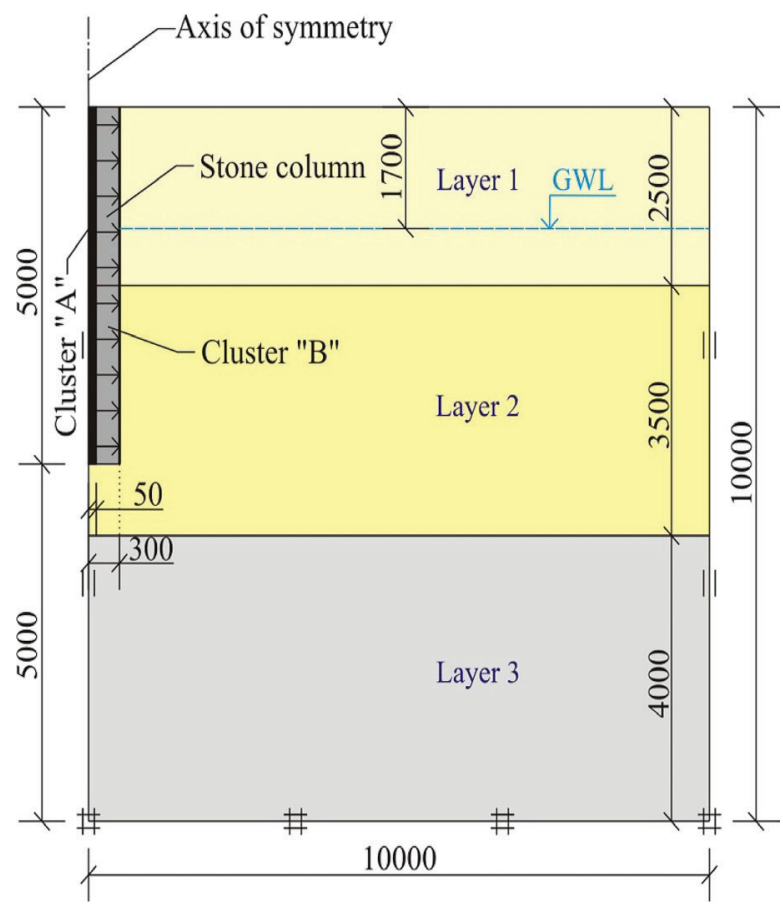

Fig. 6 Scheme of an axisymmetric numerical model of a single stone column

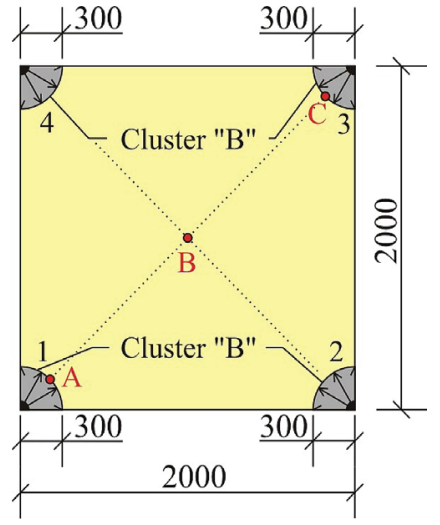

Fig. 7 The scheme of the ground plan of the model with quadrants of stone columns and the original soil between them

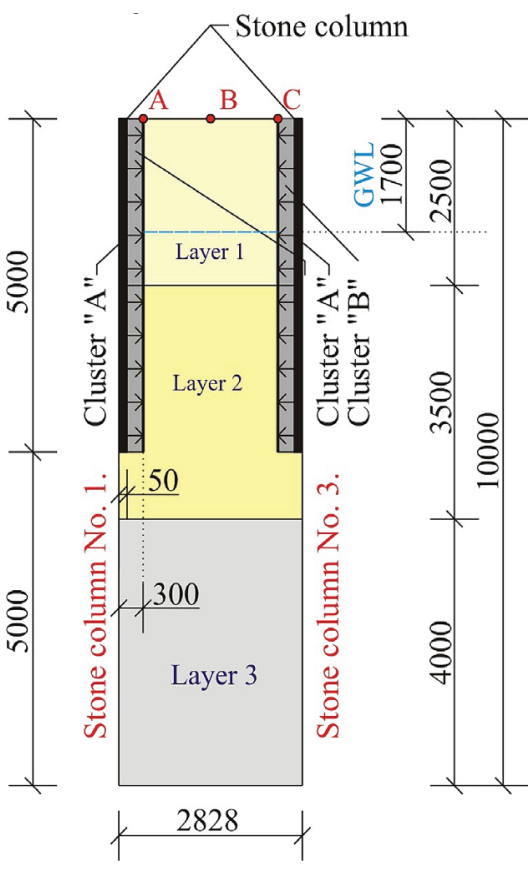

Fig. 8 Cross-section of the modelling of a numerical model of a unit cell with parts of 4 stone columns 


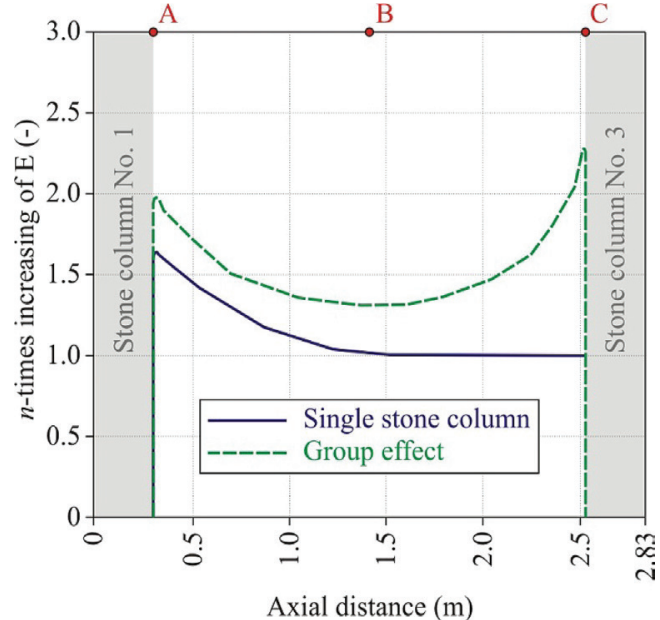

Fig. $9 \mathrm{~N}$-fold change in $E_{\text {oed }}$ in the middle of Layer 1

The results presented show that the $n$-fold increase in the oedometric modules is significantly higher if the group effect is taken into account. If only a single stone column is modelled, the increase in the oedometric modules at Point $\mathrm{A}$ is about 1.6 times greater. The effect of the compaction ended at $1.5 \mathrm{~m}$ from the stone column axis. The increase in the oedometric modules at Points B (in the middle) and C (at the shaft of stone column No. 3) is negligible.

If all the stone columns are installed, the spatial effect is taken into account; the increase in the oedometric modulus is higher at all the points. At Point A, the $n$-fold of the oedometric modulus increases from about 1.6 to about 1.95. At Point B, the $n$-fold value is about 1.3 and about 2.25 at Point C. Similar results with greater impacts were also obtained in the case of Layer 2 (Fig. 9). The installation of the stone columns causes change of vertical and horizontal geostatic stress. This impact decreases with the radial distance from stone columns axis. The spatial effect is very similar to change of the oedometer modulus as stated above. The coefficient of the lateral earth pressure was determined as a weighted average of the ratio of changed vertical and horizontal geostatic stress. The changes in the soil stresses caused by the installation of the stone column have already been presented by (Stacho, 2017b).

\section{COMPARISON OF THE CALCULATED AND MEASURED RESULTS}

The results of the analysis are presented separately for Loading step 1 (construction of the first part of the embankment to a height of about $6 \mathrm{~m}$ ) and Loading step 2 (construction of the second part of the embankment to the total height of the embankment), see Fig. 5. The results of the analysis of the construction of the first part of the road embankment (Loading step 1) are presented in Fig. 11. The installation of the consolidation layer with the geomat took about 20 days. Construction of the first part of the road embankment took place the following 30 days. The measurements show that consolidation of the first part of the embankment finished in about 100 days after the beginning of its construction. The final settlement of the road embankment base was equal to $50.2 \mathrm{~mm}$. The results of the measurements served for a detailed analysis of the numerical modelling of the road embankment founded on the improved subsoil.

The first results marked "Without stone columns" in Fig. 11 did not take into account the soil improvement using the stone columns. The final settlement was equal to $76.8 \mathrm{~mm}$, and the consolidation ended in 227 days. Model $A$ took into account the homogenisation of the subsoil. The total settlement calculated was equal to $67.0 \mathrm{~mm}$, and the

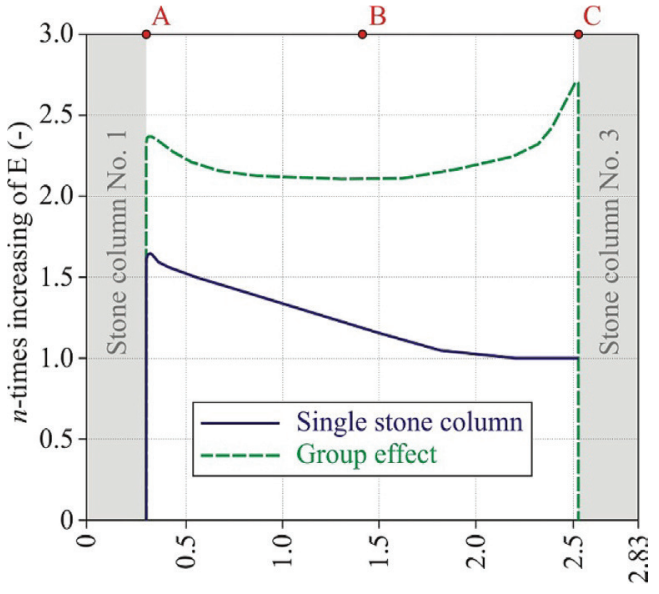

Fig. $10 \mathrm{~N}$-fold change in $E_{\text {oed }}$ in the middle of Layer 2

consolidation time was equal to 165 days. While the value of the settlement was reduced by the homogenized properties in the zone of the improvement, the time was reduced using drains. Model $B$ took into account the stone columns as continuous walls. The results of Model $B$ were similar to the results of Model A. Model C took into account the stone columns as continuous walls, and the impact of the improvement was taken into account according to the method described. The results showed that the settlement decreased to $55.9 \mathrm{~mm}$, and the time of the consolidation decreased to 105 days, which was very similar to the results of the measurements. The difference between the computed (Model C) and measured settlement was about $10 \%$.

The results of the analysis of the construction of the second part of the embankment (to the total height) are presented in Fig. 12. The construction took about 25 days. The measured settlement was equal to $55.8 \mathrm{~mm}$, and the time of the consolidation was 88 days. The results of the numerical modelling were similar to the results of Loading step 1; only the differences between each of the results increased. The settlements computed using Models $A$ and $B$ were about $75.9 \mathrm{~mm}$ and $73.4 \mathrm{~mm}$, respectively. The times required for consolidation were about 104 - 109 days. The use of Model C led to a determination of the settlement of $63.3 \mathrm{~mm}$ and the time of consolidation equal to 88 days. While the differences between the measured and calculated settlements using Models $A$ and $B$ were about $27 \%$, the differences

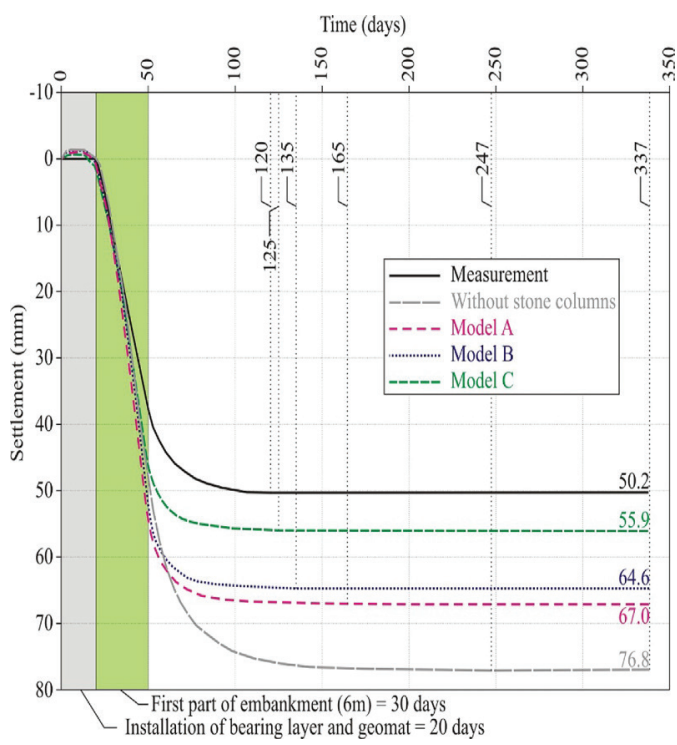

Fig. 11 Results of the analysis of Loading step 1 - the first part of the embankment 


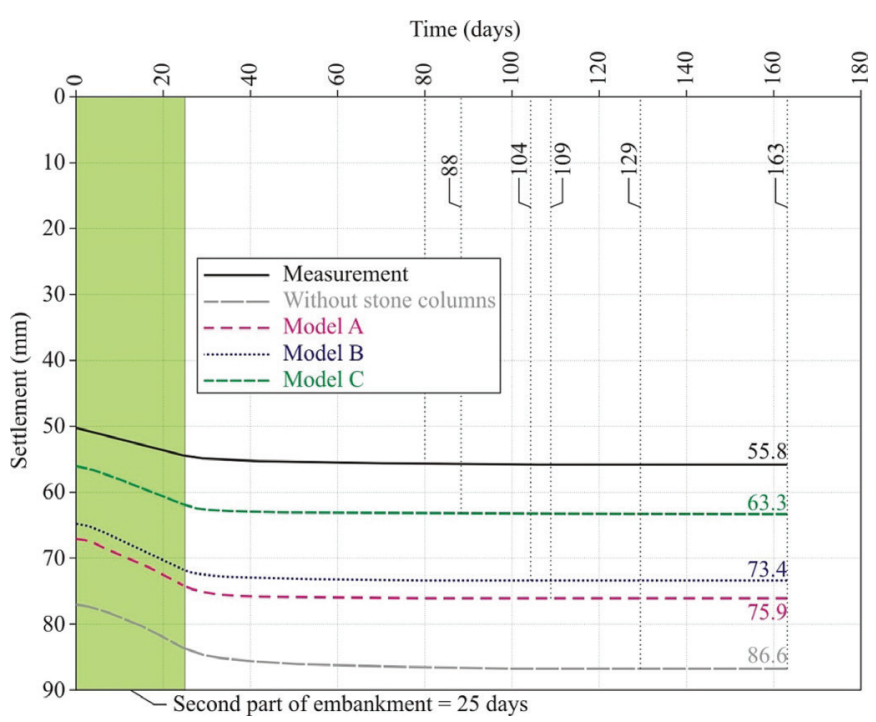

Fig. 12 Results of the analysis of Loading step 2 - the total height of the embankment

between the measurements and the results calculated using Model C were only about $11 \%$. The settlement of the top of the road embankment reached about $80 \mathrm{~mm}$. The vertical deformations of the road embankment are shown in Fig. 13.

\section{CONCLUSIONS}

The numerical modelling of soil improvement using stone columns in a plane strain model is often used in practice. Plane strain models are less difficult and time-consuming for practical solutions in comparison to full 3D models. Plane strain models require the transformation of stone columns from a $3 \mathrm{D}$ to a $2 \mathrm{D}$ task. The homogenisation of the subsoil and the transformation of the stone columns to continuous stone walls are the methods most often used in practise. The stone columns installed using the vibro-replacement technique caused a radial displace- ment of the soil and, consequently, the compaction of the soil between them. The effect of the compaction is usually not taken into account.

The article presents the numerical modelling of the soil improvement using stone columns while also taking into account the effect of the compaction between the stone columns in the plane strain model. The impact of the stone column installation and the compaction of the surrounding soil were determined using an axisymmetric model with a single stone column and the model of the unit cell, where the quadrants of the stone columns and the soil between them was modelled. These models showed that the spatial effect is significantly higher than the effect of a single stone column. The model allowed for the determination of the change in the oedometric modules and the change in the coefficient of the lateral earth pressure.

The road embankment with a height of 6.4 to $7.9 \mathrm{~m}$ was based on the subsoil improved using the stone columns. The settlement of the base of the road embankment was measured using a horizontal inclinometer. The numerical analysis presented included a comparison of the settlement measured with the results of the following numerical models: a model without any soil improvement; a model with soil improvement using homogenization of the subsoil; a model with a stone column transferred into continuous walls with the original subsoil; and a model with the stone columns transferred to continuous walls with the modelling of the soil improvement between them. The results of the analysis showed that the settlements determined using Models $A$ and $B$ were about 1.28 to 1.33 times greater than the results of the measurements in Loading step 1 and 1.31 to 1.36 times greater in Loading step 2. The results determined using Model C showed that the consideration of the improvement led to a more precise determination of the settlement as well as the consolidation time. The final settlement computed was about 1.1 times greater than the measured one. The consolidation time computed was also about 1.1 times longer than the measured one.

\section{Acknowledgement}

This article was created with the support of the Ministry of Education, Science, Research and Sport of the Slovak Republic within VEGA Grant No. 1/0842/18.

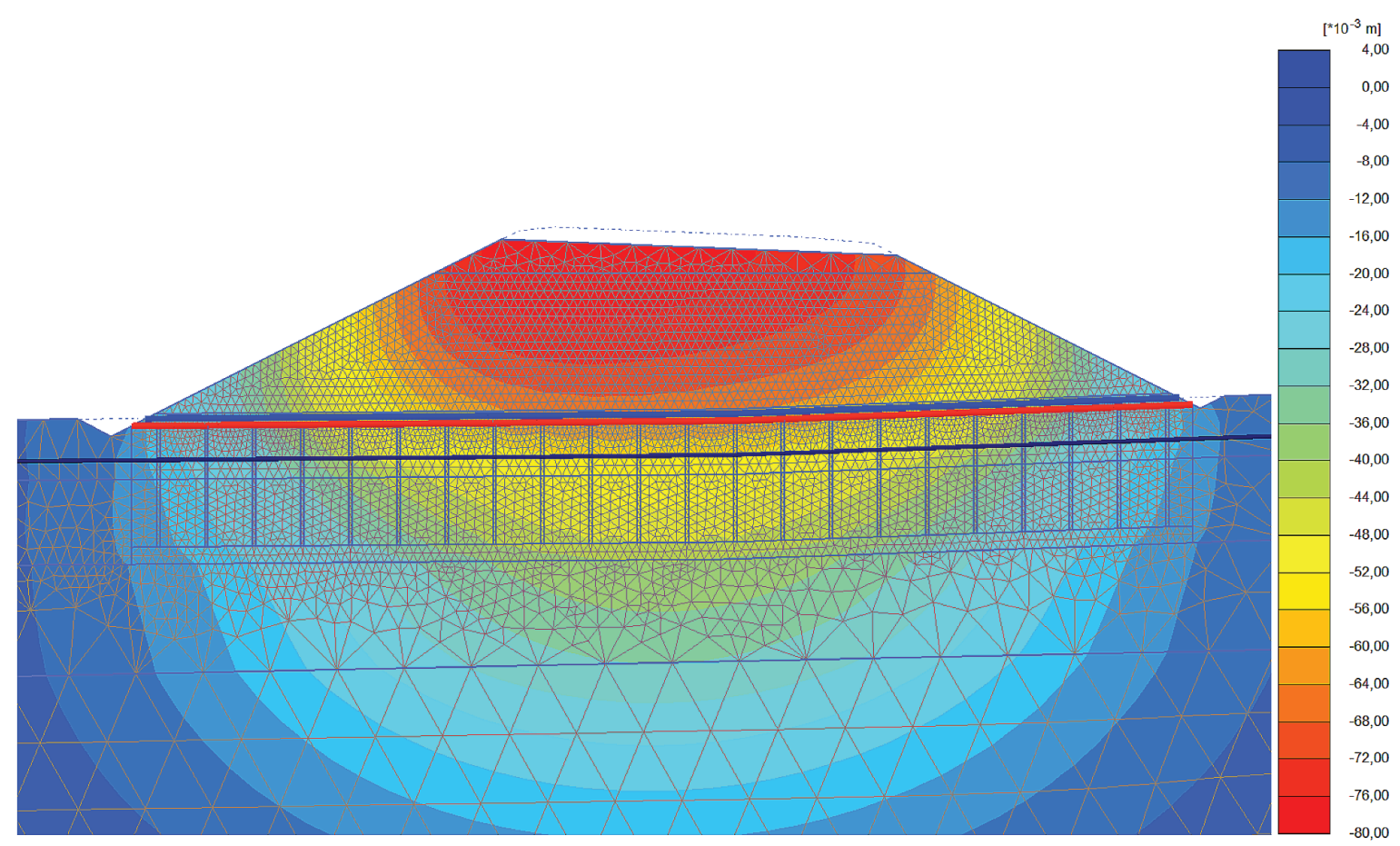

Fig. 13 Vertical deformations after the consolidation of Loading step 2 - Model C 


\section{REFERENCES}

Barksdale, R. D. - Bachus, R. C. (1983) Design and construction of stone columns, Vol. 1. Report No. FHWA/RD-83/026, Federal Highway Administration, Washington, D. C., USA, 46 pp.

Fiala, R. - Boštík, J. - Kotačková, A. - Miča, L. - Zdražil, K. - Masopust, J. (2014) Stone columns technology for practice design, implementation and control. Brno, Czech Republic, Academic Publishing CERM, 156 pp. (in Czech).

Frankovská, J. - Kopecký, M. - Mušec, P. - Janták, V. (2017) Efficiency of improvement methods in compressible soil based on the results of geotechnical monitoring. In: Proceeding of Geotechnical Issues and Practices on Deltaic Deposits and Highly Compressible Soils, 19th ICSMGE, Seoul, Korea, pp. 31 - 34 .

Greenwood, D. A. (1970) Mechanical improvement of soils below ground surface. In: Conference on Ground Engineering. London, Institute of Civil Engineering. pp. 11-22.

Hu, W. (1995) Physical modeling of group behavior of stone column foundations. Ph.D. dissertation, University of Glasgow, Glasgow, U.K., 313 pp.

Madhav, M. R. - Vitkar, P. P. (1978) Strip footing on weak clay stabilized with a granular trench or pile. In: Canadian Geotechnical Journal, No. 15(4), pp. 605-609.

Mecsi, J. (2013) Geotechnical Engineering Examples and Solutions Using the Cavity Expansion Theory. Budapest, Hungary, Geotechnical Society, 232 pp.

Plaxis - Material Models Manual (2011) 202 pp. Available at: http://www.plaxis.nl/files/files/2D2011-3-Material-Models.pdf, (accessed at 08/05/2014).

Priebe, H. J. (1995) The design of vibro replacement. In: Ground Engineering, No. 28(10), pp. 31-37.

Priebe, H. J. (2005) Design of vibro replacement. In: Ground Engineering, No. 38(1), pp. 25-27.

Shahu, J. T. - Reddy, Y. R. (2011) Clayey soil reinforced with stone column group: Model tests and analyses. In: Journal of Geotechnical and Geoenvironmental Engineering, No. 137(12), pp. 12651274.

Stacho, J. (2017a) Analysis of impact of input soil properties in numerical modelling of a stone column. In: Current geotechnical solutions and their verification. Spektrum STU, Bratislava, Slovakia, pp. 302-309.
Stacho, J. (2017b) Numerical analysis of stone columns created using different types of coarse-grained material. In: SGEM 2017. 17th International Multidisciplinary Scientific GeoConference. Vol. 17. Science and Technologies in Geology, Exploration and Mining. Sofia: STEF 92 Technology, 2017, pp. 579-586.

Stacho, J. - Frankovská, J. - Mušec, P. (2018) Numerical Analysis of Stone Columns for Road Embankment Construction. In: Proceedings of China- Europe Conference on Geotechnical Engineering. Vol. 2. Cham: Springer Nature Switzerland, 2018, pp. 1730-1733.

Stuedlein, A. W. - Holtz, R. D. (2013) Bearing capacity of spread footings on aggregate pier reinforced clay. In: Journal of Geotechnical and Geoenvironmental Engineering, No. 139(1), pp. 49-58.

Stuedlein, A. W. - Holtz, R. D. (2014) Displacement of spread footings on aggregate pier reinforced clay. In: Journal of Geotechnical and Geoenvironmental Engineering, No. 140(1), pp. 36-45.

Tran, T. A. - Mitachi, T. (2008) Equivalent plane strain modeling of vertical drains in soft ground under embankment combined with vacuum preloading. In: Computers and Geotechnics, No. 35(5), pp. 655-672.

Turček, P. - Hulla, J. - Barták, J. - Vaníček, I. - Masopust, J. Rozsypal, A. (2005) Foundation Engineering, Jaga, Bratislava, Slovakia, 359 pp. (in Czech).

VanImpe, W. F. - DeBeer, E. (1983) Improvement of settlement behaviour of soft layers by means of stone columns. In: Proceeding of the Eighth European Conference on Soil Mechanics and Foundation Engineering, Helsinki, Finland, pp. 309-312.

Vesic, A. S. (1972) Expansion of Cavities in Infinite Soil Mass. In: Journal of the Soil Mechanics and Foundation Division. No. 98, pp. 265-290.

Weber, T. M. (2009) Modeling of ground improvement with stone columns. Doctoral Thesis, ETH Zurich, 290 pp. (in German).

Wehr, W. (1999) Stone columns - The behavior of individual columns and column groups. In: Geotechnik, No. 22(1), pp. 40-47. (in German). 